\title{
SELF-MENTIONS IN APPLIED LINGUISTICS RESEARCH ARTICLES WRITTEN BY INDONESIANS AND NON-INDONESIANS
}

\author{
Slamet Utomo' ${ }^{1}$, Fitri Budi Suryani ${ }^{2}$ \\ Universitas Muria Kudus \\ e-mail:1slamet.utomo@umk.ac.id, 2fitri.budi@umk.ac.id
}

\begin{abstract}
This study explores self-mentions in Applied Linguistics research articles written by Indonesians and non-Indonesians. Twenty research articles consisting of 10 research articles written by Indonesians, and the other 10 by non-Indonesians were randomly selected from the leading and international Applied Linguistics journal published in 2017-2018. The use of first person pronouns in those articles was recorded and analyzed. The results indicate the more frequent use of self-mentions in the research articles written by Indonesians than by nonIndonesians. However, the use of first person plural pronoun is higher in the research articles written by non-Indonesians.
\end{abstract}

Keywords: self-mentions, Applied Linguistics research articles, Indonesians, non-Indonesians

\section{INTRODUCTION}

The world of academic writing is traditionally viewed as a faceless and impersonal discourse (Hyland, 2002). It is often characterized by depersonalization in which the authorial identity is minimally avoided. However, recent trends see that authors start to show their presence in their academic writing through the use of self-mentions.

Self-mentions are realized in first person pronouns together with possessive adjectives. Hyland (2001) states that self-mentions reflect the degree of confidence and authority of the authors. It is conducted consciously to "adopt a particular stance and disciplinary-situated authorial identity" (2008: 8).

Authors use personal pronouns for three main purposes, i.e., to organize argument and essay, to discuss their research activity, and to show their position towards conclusions and theoretical viewpoints (Hyland, 1999). Specifically, Ivanic (1998) argues that the use of pronoun 'I' displays the author's responsibility for the claims made.

First person pronouns consist first person singular pronouns and first person plural pronouns. First person plural pronouns include 'I', 'me', and 'my', while first person plural pronoun comprise of 'we', 'us', and 'our'. 
The first person plural pronouns 'we' together with its object and possessives can function inclusively or exclusively. When function inclusively, first person plural pronoun refers to both the author and the readers. On the contrary, first person plural pronoun can have exclusive function when it excludes the readers. Scheibman (2004: 381) notes that the use of inclusive first person plural pronoun is to "encourage the reader to maintain interest and belief in the iintegrity of the text and its arguments, and by association, by author herself'. Exclusive 'we', according to Carciu (2009: 72), is used to "emphasize personal involvement and responsibility in the research process by showing the researchers as actively nvolved in a disciplinary community working for development and progress of their discipline ". Sanz (2006: 27) explains that only first person singular pronoun 'I' and exclusive first person plural pronoun 'we' are consideres self-mentions since "they contribute to the constrcution of the author's self and academic identity".

Some studies (Sanz, 2006; Zhen-ye, 2008; Khoutyz, 2013; Behnam, Mirzapour, and Mozaheb, 2014) reveal the existence of first person pronouns used in research articles. Such studies examined the variation of the use of self-mentions between native writers and nonnative writers in their own context as well as among different disciplines. Inspite of the number of studies on self-mentions in research articles, the investigation of self-mentions between Indonesians and non-Indonesians is still rarley conducted. So, the aim of the current study is to explore the self-mentions in Applied Linguistics research articles written by Indonesian and non-Indonesian.

\section{METHOD}

The data of this study consist of twenty research articles: 10 research articles were written by Indonesian, and the other 10 were by non-Indonesian judged from their names and or institution/affiliation. The articles were randomly selected from the leading and international Applied Linguistics journal, that is the Indonesian Journal of Applied Linguistics (IJAL) published in 2017-2018.

The quantitative analysis was conducted in which the number of occurrences of first person pronouns was recorded for both research articles written by Indonesians and nonIndonesians. The calculation was also done for the types of first person pronouns, both singular and plural. 


\section{RESULTS AND DISCUSSION}

To find out the use of self-mentions in Applied Linguistics research artiles written by Indonesians and non-Indonesians, the data analysis yielded the following results.

Table 1. Frequency and percentage of first person pronouns

\begin{tabular}{lllll}
\hline Category & $\begin{array}{l}\text { Articles } \\
\text { Indonesians }\end{array}$ & written & by & $\begin{array}{l}\text { Articles written by non- } \\
\text { Indonesians }\end{array}$ \\
& 44 & 34 &
\end{tabular}

The results in table 1 indicate that the number of first person pronouns used in the articles written by Indonesians is 44 , meanwhile the number of first person pronouns in the articles written by non-Indonesians is 34 . This means that Indonesians used first person pronouns more often than non-Indonesians in their research articles. The detail use of first person pronouns in the research articles written by Indonesians and non-Indonesians is presented in the table below.

Table 2. Frequency and percentage of the kinds of first person pronouns

\begin{tabular}{llll}
\hline Category & $\begin{array}{l}\text { Articles } \\
\text { Indonesians }\end{array}$ & written & $\begin{array}{l}\text { Articles written by non- } \\
\text { Indonesians }\end{array}$ \\
\hline $\mathrm{I}$ & $2.27 \%$ & $0 \%$ \\
\hline $\mathrm{Me}$ & $0 \%$ & $0 \%$ \\
\hline $\mathrm{My}$ & $0 \%$ & $0 \%$ \\
\hline We & $90.91 \%$ & $94.12 \%$ \\
\hline Us & $0 \%$ & $0 \%$ \\
\hline Our & $6.82 \%$ & $5.88 \%$
\end{tabular}

As table 2 shows, there are only three kinds of first person pronouns used in the Appkied Linguistics research articles written by Indonesians and non-Indonesians: "I", "we", and "our". The other kinds of first person pronoun ("me", "my",and "us") do not appear in the research articles. The most frequently used first person pronoun in the research articles written by Indonesians and non-Indonesians is "we". Non-Indonesians use it in their research articles more frequently (94.12\%) than Indonesians do (90.01\%). The possessive adjective of first person plural pronoun "our" falls into the second mostly used in the research articles in which Indonesian writers $(6.82 \%)$ use it more often than non-Indonesians $(5.88 \%)$. The first person 
singular pronoun "I" is the least used in the research articles. In the research articles written by Indonesians, "I" was only used $2.27 \%$, whereas non-Indonesians did not use it in their research articles.

The least use of first person singular pronoun in Indonesians research articles and none in non-Indonesians research articles might depict the tendency of authors not to exhibit their authorial presence in their work. Moreover, this can show that authors avoid responsibility towards their claims in writing their research articles as Ivanic (1998) states that the use of pronoun 'I' displays the author's responsibility for the claims made. Therefore, the absence of the use of first person singular pronoun "I" indicates the reluctance of the authors to take responsibility for their articles. This is in line with Ivanic (1998: 306) who notes that by not using "I", "the writer is withdrawing from all responsibility of his or her writing".

In the data, the use of first person singular pronoun "I" appear in method section when the author explains the instrument of his study.

“.... I adapted Taguchi et al.'s (2009) three items related to learners' situation-specific motives..."

The results of the analysis reveal that the number of the use of the exclusive first person plural pronoun is the most frequent. It was found in the research articles written by two or more than two authors. This might show that the authors actually are not reluctant to take responsibility of their writing. They display their presence as well as responsibility as Carciu (2009: 73) argues that "exclusive "we" emphasizes personal involvement and responsibility".

The use of "we" in Applied Linguistics research articles written by Indonesians and nonIndonesians appear to explain the research method taken by authors. This indicates that the authors take responsibility for the choices that they made in conducting their research.

“.... we recruited eleven novice teachers of English to participate in the study..."

"We examined how the pictures in the picture books, and the embodied delivery..."

In addition, "we" is used to mark authors' stance of their work which establishes their commitment to the field.

"We argue that there is a need to place a greater emphasis on the language proficiency..."

"We argue that this skill also extends to readers of L2 English."

Such expressions belong to a strong self which makes authors "seen in a text presenting the extent and importance of their contribution" (Carciu, 2009: 78). Both Indonesians and nonIndonesians use such kind of first person plural pronoun "we" in their research articles. 
The possessive adjective "our", as Carciu (2009) claims, has intermediate form to mark the explicit presence of author. Indonesians tend to use it more frequently than non-Indonesians in the research articles.

“..., we will compare Day and Bamford's (1998) ER with our delivery of ARR”.

"Before this study commenced, we negotiated our research project with the participants...".

In the data, the possessive form "our" is found to be used mainly with "we" in research articles written by both Indonesians and non-Indonesians. This shows that "our" takes less visible stance compared to "we". However, it still exhibits the authorial identity as well as responsibility of the claims made.

\section{CONCLUSION}

The current study has examined the use of self-mentions in Applied Lingustics research articles written by Indonesians and non-Indonesians. The results indicate that both Indonesians and non-Indonesians display the use of first person pronouns.

The Indonesian authors tend to use self-mentions in Applied Linguistics research articles more frequently than non-Indonesians. The absence of the use of firts person singular pronoun "I" in the articles written by non-Indonesians also show that Indonesians prefer to make themselves more visible than the non-Indonesians.

However, non-Indonesians display the use of first person plural pronoun "we" in Applied Linguistics research articles higher than Indonesians do. The functions of "we" that both Indonesians and no-Indonesians use do not perform differences. This is also found for the possesive adjective "our" which comes as the less visible form.

The results suggest the need to raise authors' awareness in presenting themselves in the text and take more responsibility of their writing. It can be started and done in such class as academic writing where instructions about the use of self-mentions in writing are given.

\section{REFERENCES}

Behnam, B., Mirzapour, F, \& Mozaheb, M. A.. 2014. Writer's presence in English native and non-native speaker research articles. International Conference on Current Trends in ELT. Procedia (98), pp. 369-374. 
Carciu, O.M. 2009. An intercultural study of firts person plural references in biomedical writing. Iberica, 18, pp. 71-92.

Hyland, K. 1999. Disciplinary discourses: Writer stance in research articles. In C. Candlin and K. Hyland (eds.). Writing: Texts, processes and practices, 99-121. London and New York: Longman.

Hyland, K. 2001. Humble servants of the discipline? Self-mention in research articles. English for Specific Purposes, 20, pp. 207-226.

Hyland, K. 2002. Options of identity in academic writing. ELT Journal, 56 (4), pp. 351-358.

Hyland, K. 2008. Persuasion, interaction and the construction of knowledge: representing self and others in research writing. International Journal of English Studies, 8 (2), pp. 1-23.

Ivanic, R. (1998). Writing and identity: The discoursal construction of identity in academic writing. Amsterdam: Benjamin.

Khoutyz, I. 2013. Engagement features in Russian and English: a cross-cultural analysis of academic written discourse. TESOL and Applied Linguistics, 13 (1), pp. 1-20.

Sanz, R.L. 2006. 'I will argue that': first person pronoun as metadiscoursal devices in research article abstracts in English and Spanish. ESP Across Cultures.3. pp. 23-40.

Scheibman, J. 2004. Inclusive and exclusive patterning of the English first person plural: evidence from conversation. In M. Achard and S. Kemmer (eds.). Language, Culture, and Mind, 377-396. California: CSLI Publications.

Zhen-ye, N. 2008. A genre based analysis of English reseach article abstract and linguistic feature of personal pronouns for financial economics. US-China Education Review, 5 (7), pp. 62-65. 